\title{
Herbal Formulation C168 Attenuates Proliferation and Induces Apoptosis in HCT 116 Human Colorectal Carcinoma Cells: Role of Oxidative Stress and DNA Damage
}

\author{
Lek Mun Leong, ${ }^{1}$ Kok Meng Chan, ${ }^{2,3}$ Asmah Hamid, ${ }^{1,3}$ \\ Jalifah Latip, ${ }^{4}$ and Nor Fadilah Rajab ${ }^{1,3}$ \\ ${ }^{1}$ Biomedical Science Programme, School of Diagnostic and Applied Health Science, Faculty of Health Sciences, \\ Universiti Kebangsaan Malaysia, Jalan Raja Muda Abdul Aziz, 50300 Kuala Lumpur, Malaysia \\ ${ }^{2}$ Environmental Health and Industrial Safety Programme, School of Diagnostic and Applied Health Science, \\ Faculty of Health Sciences, Universiti Kebangsaan Malaysia, Jalan Raja Muda Abdul Aziz, 50300 Kuala Lumpur, Malaysia \\ ${ }^{3}$ Toxicology Laboratory, Faculty of Health Sciences, Universiti Kebangsaan Malaysia, Jalan Raja Muda Abdul Aziz, \\ 50300 Kuala Lumpur, Malaysia \\ ${ }^{4}$ School of Chemical Science and Food Technology, Faculty of Science and Technology, Universiti Kebangsaan Malaysia, \\ Jalan Reko, 43600 Bangi, Selangor, Malaysia
}

Correspondence should be addressed to Nor Fadilah Rajab; nfadilah@ukm.edu.my

Received 3 September 2015; Accepted 8 December 2015

Academic Editor: Nunziatina De Tommasi

Copyright (C) 2016 Lek Mun Leong et al. This is an open access article distributed under the Creative Commons Attribution License, which permits unrestricted use, distribution, and reproduction in any medium, provided the original work is properly cited.

\begin{abstract}
The use of herbal formulations has gained scientific interest, particularly in cancer treatment. In this study, the herbal formulation of interest, denoted as C168, is a mixture of eight genera of plants. This study aims to investigate the antiproliferative effect of C168 methanol extract (CME) on various cancer cells and its underlying mechanism of action on the most responsive cell line, namely, HCT 116 cells. CME exerted antiproliferative activities on HCT 116 colorectal carcinoma cells and HepG2 hepatocellular carcinoma cells but not on CCD-841-CoN normal colon epithelial cells, Jurkat E6.1 lymphoblastic leukemic cells, and V79-4 Chinese

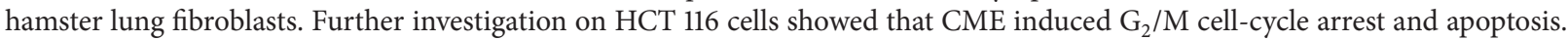
Treatment of CME induced oxidative stress in HCT 116 cells by increasing the superoxide anion level and decreasing the intracellular glutathione. CME also increased tail moment value and H2AX phosphorylation in HCT 116 cells, suggesting DNA damage as an early signal of CME induced apoptosis. Loss of mitochondrial membrane potential in CME-treated cells also indicated the involvement of mitochondria in CME induced apoptosis. This study indicated the selectivity of CME toward colon cancer cells with the involvement of oxidative damage as its possible mechanism of action.
\end{abstract}

\section{Introduction}

Traditional Chinese medicine (TCM) is an important component in complementary and alternative medicine. TCM has evolved for a thousand years on the basis of its unique system of theories. One of the principal theories proposed in the classic TCM text Yellow Emperor's Internal Cannon was the balance between vital $q i$ and pathogenic $q i$ in the human body [1]. This principle has been widely used in designing formulations to treat various diseases. TCM has gained increasing scientific interest in cancer treatment over the years.
The role of TCM in the following three aspects of cancer therapy has been extensively explored: prevention of tumorigenesis, reduction of side effects and enhancement of efficacy of conventional therapy, and reduction of tumor recurrence and metastasis [1].

Among various forms of TCM therapies, such as herbal medicine, acupoint stimulation, massage, TCM psychological intervention, and qigong, herbal medicine is the most frequently applied TCM therapy for cancer patients [2]. Herbal formulation is a mixture of herbs designed for a specific condition or disease. Examples of herbal formulations 
with scientific evidence in the treatment of colon cancer include Pi-Sheng decoction, Yi-Qi-Zhu-Yu decoction, Jian$P i-X i a o-L i u$ decoction, Jian-Qi-Jie-Du decoction, Jian-Pi-Yi$\mathrm{Qi}$ decoction, and Fu-Pi-Yi-Wei decoction [3]. Combination of multiple drugs as a formulation provides the advantage of targeting multiple mechanisms in a disease to enhance treatment [4].

Colorectal cancer is a common malignant neoplasm prevalent in both developed and developing countries $[5,6]$. This disease ranks second among causes of cancer-related deaths worldwide, comprising $10 \%-15 \%$ of all forms of cancer [7]. Cancer led to 7.6 million deaths globally in 2008 and remains a healthcare burden in terms of managing the disease [8].

Chemotherapy agents used for colorectal cancer include 5-fluorouracil (5-FU), capecitabine, leucovorin, and oxaliplatin [7]. Each chemotherapeutic agent demonstrates a distinct mechanism of action. For instance, 5-FU, a commonly used chemotherapeutic agent, and its prodrug capecitabine exert antiproliferative effects by generating thymidylate stress [7]. Leucovorin is often incorporated into the 5-FU regimen as a combinatorial treatment to enhance the clinical effects of 5-FU by serving as a substrate to form $\mathrm{N}^{5}, \mathrm{~N}^{10}$-methylene tetrahydrofolate $\left(\mathrm{CH}_{2} \mathrm{H}_{4}\right.$ PteGlu). $\mathrm{N}^{5}, \mathrm{~N}^{10}$ Methylene tetrahydrofolate serves as a rate-limiting cofactor in 5-FU inhibition of thymidylate synthesis. Oxaliplatin is a platinum-based cytotoxic agent that forms DNA-platinum adducts to inhibit cell growth [9]. Current clinical approaches to colorectal cancer focus on combinatorial regimens, such as the Mayo Clinic regimen, de Gramont regimen, modified de Gramont regimen, and FOLFOX [10]. Therefore, C168 was formulated through the combination of different herbs to achieve the beneficial effect of a combinatorial regimen.

However, most cancer treatments remain inadequate and far from desired perfection [11]. Commonly used chemotherapeutic agents are often associated with multiple side effects of the treatment dose [12]. Chemotherapy drugs such as oxaliplatin, etoposide, and 5-FU cause peripheral neuropathy, myelosuppression, and leukopenia, respectively [13-15]. To address these issues, studies are conducted on the combination of multiple natural products or of natural products with conventional drugs to enhance the therapeutic effect of these drugs, with the hope of reducing their side effects [16-19]. One of the combinations that underwent research was the combination of notoginseng extract with 5-FU to enhance the efficacy of 5-FU in colorectal cancer cell lines [16].

In the present study, the herbal formulation of interest, denoted as C168, contained eight different genera of plant which include Cinnamomum spp., Zingiber spp., Atractylodes spp., Carthamus spp., Angelica spp., Curcuma spp., Glycyrrhiza spp., and Astragalus spp. The formulation and species of herbs were not disclosed for the reasons related to intellectual property protection. Several genera found in herbal formulation C168 have been recognized to exert antiproliferative effects on colorectal cancer cell lines individually. These genera include Cinnamomum spp., Zingiber spp., and Astragalus spp. [20-25]. An anecdotal report claimed that the herbal formulation C168 relieved the symptoms of colon cancer and served as a potential natural product for colon cancer treatment. However, no scientific evidence has been presented to validate these claims. Therefore, the current study focuses on the antiproliferative effect of C168 methanol extract (CME), as well as its underlying mechanism of action.

\section{Materials and Methods}

2.1. Chemicals and Cell Lines. All chemicals were purchased from Sigma (USA) unless stated otherwise. HCT 116 human colorectal carcinoma cells, CCD-841-CoN normal colon epithelial cells, Jurkat E6.1 lymphoblastic leukemic cells, HepG2 hepatocellular carcinoma cells, and V79-4 Chinese hamster lung fibroblasts were obtained from American Type Culture Collection (Rockville, MD USA). CCD-841-CoN and V79-4 cells were maintained in Dulbecco's Modified Eagle's Medium (DMEM), whereas HepG2 and Jurkat E6.1 cells were maintained in Eagle Minimum Essential Medium (EMEM) and RPMI 1640 medium, respectively. All mediums were purchased from Gibco Invitrogen, USA, and supplemented with $10 \%$ fetal bovine serum (PAA Laboratories, $\mathrm{GmbH}$ ) and $100 \mathrm{U} / \mathrm{mL}$ of Penicillin-Streptomycin (PAA Laboratories, $\mathrm{GmbH})$. Cells were cultured at $37^{\circ} \mathrm{C}$ in $5 \% \mathrm{CO}_{2}$ condition at the Toxicology Laboratory, Faculty of Health Science, Universiti Kebangsaan Malaysia.

2.2. Preparation of C168 Methanol Extract (CME). C168 in powder form was provided by Inchoice Technology Sdn. Bhd. (Selangor, Malaysia). C168 consisted of seven genera of Chinese herbs, namely, Cinnamomum spp., Zingiber spp., Atractylodes spp., Carthamus spp., Angelica spp., Curcuma spp., Glycyrrhiza spp., and Astragalus spp. C168 powder was macerated with methanol (Merck, Malaysia) for 72 hours and filtered using a Whatman filter paper. The solvent was dried by rotary evaporation, followed by freeze drying. The extract was then reconstituted in DMSO (Ajax Finechem, Thermo Fisher Scientific) to prepare $800 \mathrm{mg} / \mathrm{mL}$ stock solution for in vitro testing.

2.3. Cell Plating and Treatment In Vitro. HCT 116, V79-4, HepG2, and CCD-841-CoN cells were plated at a density of $2 \times 10^{4} / \mathrm{cm}^{2}$, whereas Jurkat E6.1 cells were plated at a seeding concentration of $1 \times 10^{6}$ cells $/ \mathrm{mL}$. Cells were allowed to stand overnight for cell attachment. CME treatment was administered in a concentration-dependent or time-dependent manner as indicated in each subsection.

2.4. Cell Viability Assay. MTT [3-(4,5-dimethyl-2-thiazolyl)2,5-diphenyl-2H-tetrazolium bromide] assay was performed to determine the cytotoxicity effect of CME on a panel of cell lines, namely, HCT 116, CCD-841-CoN, HepG2, Jurkat E6.1, and V79-4 cells, as previously described [26]. Plating was performed in a 96-well plate and treated with CME for 24 hours. MTT solution $(5 \mathrm{mg} / \mathrm{mL})$ was added following incubation at a final concentration of $0.5 \mathrm{mg} / \mathrm{mL}$ and further incubated for 4 hours. Supernatant was removed, and DMSO was added to dissolve the formed formazan crystal. The plate was further incubated for 15 minutes prior to measurement at 
$570 \mathrm{~nm}$ with an ELISA plate reader (Bio-Rad, USA). Cell viability was calculated as follows:

$$
\% \text { viability }=\frac{\text { optical density of sample }}{\text { optical density of control }} \times 100 \% .
$$

The cell line with the most potent $\mathrm{IC}_{50}$ was selected for further evaluation for the possible CME mechanism of action.

2.5. Annexin V-FITC/PI Labeling Assay. The mode of cell death induced by CME was assessed as previously described [27]. On the basis of the $\mathrm{IC}_{50}$ obtained by MTT assay, HCT 116 cells were selected as the model to be used for the present and subsequent studies. HCT 116 cells were treated with various concentrations of CME for 72 hours. The CME-treated HCT 116 cells were harvested and then washed with chilled PBS prior to suspension in Annexin binding buffer $(\mathrm{ABB})$ at $1 \times 10^{6}$ cells $/ \mathrm{mL}$. Subsequently, $100 \mu \mathrm{L}$ of cell suspension was transferred to a polystyrene round-bottom tube and stained with $5 \mu \mathrm{L}$ of Annexin V-FITC (BD Bioscience, USA) for 15 minutes and then with $5 \mu \mathrm{L}$ of propidium iodide $(50 \mu \mathrm{g} / \mathrm{mL})$ for 2 minutes. Staining was performed in dark at room temperature. Afterward, $400 \mu \mathrm{L}$ of ABB was added to the stained cells prior to analysis with FACSCanto II flow cytometer (BD Bioscience, USA).

2.6. Trypan Blue Dye Exclusion Test. The total number of cells was assessed using the trypan blue dye exclusion test. HCT 116 cells were treated with various concentrations of CME for 24 hours before they were harvested. Cells were centrifuged ( $2500 \mathrm{rpm}, 5$ minutes, $4^{\circ} \mathrm{C}$ ) before $3 \mathrm{~mL}$ of complete culture media was added. Subsequently, $100 \mu \mathrm{L}$ of cell suspension was added to $400 \mu \mathrm{L}$ of $0.4 \%$ trypan blue reagent and then mixed thoroughly. Cell count was assessed using a hemocytometer. Under a light microscope, the cells that picked up trypan blue dye were identified as dead cells, whereas those that excluded trypan blue were identified as viable cells. The number of viable cells and that of dead cells were calculated and recorded.

2.7. Cell-Cycle Analysis. Cell-cycle distribution was determined as previously described [28]. Briefly, $5 \times 10^{5}$ CMEtreated cells were washed with $30 \mathrm{~mL}$ of chilled PBS, centrifuged $\left(2500 \mathrm{rpm}, 5\right.$ minutes, $4^{\circ} \mathrm{C}$ ), fixed with $70 \%$ ethanol overnight, and then centrifuged again. Subsequently, $1 \times 10^{5}$ cells were stained with $500 \mu \mathrm{L}$ of PI solution (BD Bioscience, USA) for 15 minutes at room temperature. Stained cells were analyzed using FACSCanto II flow cytometer (BD Bioscience, USA) installed with ModFit LT (Verity Software House).

2.8. Assessment of Reactive Oxygen Species. Reactive oxygen species (ROS) content was assessed by hydroethidine staining as previously described [27]. C168 treatment was administered at different time-point intervals before HCT 116 cells were harvested. CME-treated cells were washed with chilled PBS and then suspended in serum-free medium containing $1 \mu \mathrm{L}$ of $10 \mathrm{mM}$ hydroethidine (Gibco, Invitrogen). Staining was performed in dark ( 30 minutes, $37^{\circ} \mathrm{C}$ ), and the cells were washed prior to suspension in $500 \mu \mathrm{L}$ of chilled PBS and analysis with FACSCanto II flow cytometry (BD Bioscience, USA).

2.9. Determination of Intracellular Free Thiol Level. Intracellular free thiol level was determined as previously described [29]. CME-treated cells were washed with chilled PBS, and $100 \mu \mathrm{L}$ of chilled lysis buffer $\left(50 \mathrm{mM} \mathrm{K}_{2} \mathrm{HPO}_{4}, 1 \mathrm{mM}\right.$ EDTA, $\mathrm{pH} 6.5$, and $0.1 \% \mathrm{v} / \mathrm{v}$ Triton-X-100) was added. Cells were incubated $\left(4^{\circ} \mathrm{C}, 15\right.$ minutes) for lysis process to occur, followed by centrifugation (12000 rpm, 15 minutes, $\left.4^{\circ} \mathrm{C}\right)$. Supernatant was collected as protein lysate. Protein concentration was determined using Bradford protein assay, whereas the glutathione level was assessed using Ellman assay. The standard curve of glutathione was generated using a set of standard solutions ranging from $1.25 \mathrm{mM}$ to $4.88 \mu \mathrm{M}$. This step was performed by reconstituting the reduced glutathione with a reaction buffer at $\mathrm{pH} 6.5\left(0.1 \mathrm{M} \mathrm{Na}_{2} \mathrm{HPO}_{4} \cdot 7 \mathrm{H}_{2} \mathrm{O}\right.$ and $1 \mathrm{mM}$ EDTA, pH 6.5). Subsequently, $50 \mu \mathrm{L}$ of the sample was added into a 96-well plate, followed by $40 \mu \mathrm{L}$ of reaction buffer at $\mathrm{pH} 8\left(0.1 \mathrm{M} \mathrm{Na}_{2} \mathrm{HPO}_{4} \cdot 7 \mathrm{H}_{2} \mathrm{O}\right.$ and $1 \mathrm{mM}$ EDTA, $\mathrm{pH} 8$ ) and $10 \mu \mathrm{L}$ of dithiobis(2-nitrobenzoic acid) (DTNB) $(4 \mathrm{mg} / \mathrm{mL})$. Reaction mixtures were incubated for 15 minutes, and absorbance was read at $415 \mathrm{~nm}$. The concentration of free thiol in cell lysate was calculated and expressed as nmol glutathione/mg protein.

2.10. Alkaline Comet Assay. Alkaline comet assay was performed as previously described to access DNA damage induced by CME [30]. CME-treated HCT 116 cells were harvested and washed twice with $\mathrm{Ca}^{2+}, \mathrm{Mg}^{2+}$-free PBS. Cell pellets were then mixed thoroughly with $0.6 \%$ low melting point agarose and laid on hardened $0.6 \%$ normal melting agarose. The agarose was allowed to solidify and subsequently placed in a chilled lysis buffer (2.5 M NaCl, $100 \mathrm{mM}$ EDTA, $10 \mathrm{mM}$ Tris, and $1 \%$ Triton-X) for lysis to occur. Slides were then incubated in an electrophoresis buffer $(0.3 \mathrm{~N} \mathrm{NaOH}, 1 \mathrm{mM}$ EDTA) for 20 minutes to facilitate DNA unwinding. Electrophoresis was performed under $25 \mathrm{~V}, 300 \mathrm{~mA}$ for $20 \mathrm{~min}$ utes. Subsequently, slides were rinsed with neutralizing buffer ( $400 \mathrm{mM}$ Tris) thrice prior to staining with $10 \mu \mathrm{g} / \mathrm{mL}$ ethidium bromide solution. Slides were kept overnight before they were observed under fluorescence microscope (Olympus, Japan) and then analyzed with CometScore (Tritek Corp., USA).

2.11. Assessment of Mitochondrial Membrane Potential. Mitochondrial membrane potential (MMP) was assessed as previously described [31]. CME-treated HCT 116 cells were suspended in $1 \mathrm{~mL}$ of serum-free media, added with $1 \mu \mathrm{L}$ of $50 \mu \mathrm{M}$ tetramethylrhodamine ethyl ester (TMRE) (Molecular Probes, Invitrogen). The cells were incubated in the dark for staining purposes $\left(15\right.$ minutes, $\left.37^{\circ} \mathrm{C}\right)$, followed by centrifugation $\left(2500 \mathrm{rpm}, 5\right.$ minutes, $\left.4^{\circ} \mathrm{C}\right)$. The stained cells were washed with chilled PBS once prior to suspension in $500 \mu \mathrm{L}$ of PBS and then analyzed with FACSCanto II flow cytometer (BD Bioscience, USA).

2.12. Western Immunoblot Analysis. Western blot analysis was performed as previously described to access the level 
of phosphorylated H2AX [32]. HCT 116 cells were treated with $500 \mu \mathrm{g} / \mathrm{mL}$ CME at various time points and then harvested via scrapping. Cell lysates were collected, and protein samples were denatured at $95^{\circ} \mathrm{C}$ for 5 minutes. Subsequently, $20 \mu \mathrm{g} / \mathrm{mL}$ protein lysate was resolved in $15 \%$ SDS-polyacrylamide gel and blotted on a polyvinylidene fluoride membrane. Rabbit phosphorylated H2AX antibody was added to the blot and then allowed to incubate at room temperature for 2 hours. Meanwhile, rabbit monoclonal beta-actin was used to detect beta-actin as loading control. Following incubation of primary antibody, a secondary antibody (goat anti-rabbit HRP conjugated antibody) was added and incubated at room temperature for 1 hour prior to detection by chemiluminescence method. All antibodies were purchased from Cell Signaling Technology (Massachusetts, USA).

2.13. Phytochemical Screening. Phytochemical screening was performed using the techniques described below $[33,34]$.

2.13.1. Alkaloid Screening. Up to $500 \mathrm{mg}$ of CME was added into chloroform until a thick slurry was formed. Thereafter, $10 \mathrm{~mL}$ of ammonium chloroform was added into the mixture and filtered into a test tube. Following this step, $1 \mathrm{~mL}$ of $2 \mathrm{M}$ sulfuric acid was added and allowed to stand for 5 minutes. An aqueous layer was obtained, and Mayer's reagent was added. Any precipitation indicated the presence of alkaloid.

2.13.2. Triterpenoid Screening. Up to $500 \mathrm{mg}$ of CME was added into $4 \mathrm{~mL}$ of acetic anhydride and heated to boiling temperature. The extract was then cooled, and $1 \mathrm{~mL}$ of concentrated sulfuric acid was added along the side of the test tube. Formation of pink color indicated the presence of triterpenoid.

2.13.3. Phenolic Compound Screening. CME was dissolved in $70 \%$ ethanol. Equal volume of 5\% iron(III) chloride solution was added into the extract and then mixed. A deep bluish green solution indicated the presence of phenolic compounds.

2.13.4. Saponin Screening. Up to $2 \mathrm{~mL}$ of distilled water was added to $2 \mathrm{~mL}$ of the extract and then shaken vigorously. Stable persistent froth indicated the presence of saponin.

2.14. Statistical Analysis. Statistical Package of the Social Science (SPSS) version 20 (IBM Corp., New York, USA) was used for statistical analysis. Data were expressed as means \pm standard error of mean (SEM). The results of Annexin VFITC/PI labeling assay, trypan blue dye exclusion test, cellcycle analysis, ROS content analysis, intracellular free thiol level determination, alkaline comet assay, and MMP assessment were all analyzed using one-way ANOVA. Dunnett's post hoc test was used to identify significant treatment effects $(p<0.05)$ for the abovementioned assay. A value of $p<0.05$ was considered statistically significant.

\section{Results}

3.1. CME Exerted the Highest Antiproliferative Effect on HCT 116 Colorectal Carcinoma Cells In Vitro. CME exerted antiproliferative effects on HepG2 $\left(\mathrm{IC}_{50}=770 \mu \mathrm{g} / \mathrm{mL}\right)$ and HCT 116 cells $\left(\mathrm{IC}_{50}=340 \mu \mathrm{g} / \mathrm{mL}\right)$ but not on Jurkat E6.1, V794, and CCD-841-CoN cells. The CME antiproliferative effect on HCT 116 and HepG2 cells was found to be concentration dependent. Our results demonstrated CME selective cytotoxicity toward colorectal cancer cells but not toward normal colon epithelial cells. Therefore, HCT 116 cells were used to elucidate the CME mechanism of action on the basis of the potency and selectivity of CME on colorectal cancer cells (Figure 1).

3.2. CME Decreased Proliferation of HCT 116 Cells following 24-Hour Treatment. CME decreased the proliferation of HCT 116 cells after 24-hour treatment when examined using the trypan blue dye exclusion test. CME treatment as low as $125 \mu \mathrm{g} / \mathrm{mL}$ significantly decreased the HCT 116 viable cells compared with the control population after 24 hours $(p<$ 0.05 ). However, no significant increase in the number of dead cells relative to the control population was observed up to a concentration of $500 \mu \mathrm{g} / \mathrm{mL}$. This finding suggests that CME exerted its antiproliferative effect primarily by inhibiting the rapid growth of cells with no massive cell death (Figure 2).

3.3. CME Induced Cell-Cycle Arrest in HCT 116 Cells. Cellcycle analysis was performed to elucidate the involvement of cell-cycle arrest in the CME mechanism of action. Following 24-hour treatment, the $\mathrm{G}_{2} / \mathrm{M}$ population of the HCT 116 cells $(26.22 \% \pm 0.6 \%)$ was higher than that of the negative control $(20.10 \% \pm 1.7 \%)$. This finding suggests that CME affected the cell-cycle distribution, thereby decreasing the proliferation of HCT 116 cells (Figure 3).

3.4. CME Induced Apoptosis in HCT 116 Cells. Treatment of CME was extended to 72 hours to investigate the mode of cell death in HCT 116 cells. Thus, Annexin V-FITC/PI dual staining was employed. The results of Annexin V-FITC/PI dual staining demonstrated that CME induced apoptosis in a concentration-dependent manner. At a concentration of $500 \mu \mathrm{g} / \mathrm{mL}$, CME induced $29.30 \% \pm 4.7 \%$ early apoptotic events and $21.77 \% \pm 2.9 \%$ late apoptotic events in the treatment groups, compared with $5.3 \% \pm 0.8 \%$ early apoptotic events and $9.2 \% \pm 0.9 \%$ late apoptotic events in the negative control $(p<0.05)$. Together with the previous data, the current results indicated that CME decreased the proliferation of HCT 116 cells followed by inducing apoptosis (Figure 4).

3.5. CME Induced Oxidative Stress in HCT 116 Cells. Many studies have demonstrated that oxidative stress is an early signal of apoptosis in cancer cells. Hence, oxidative stress was investigated to understand the mechanism of CME induced apoptosis. Investigation was conducted using $500 \mu \mathrm{g} / \mathrm{mL}$ CME because this concentration induced massive apoptotic events in HCT 116 cells. ROS contents, specifically superoxide anion and intracellular glutathione, were measured to assess the redox status of the CME-treated cells. Our data revealed 


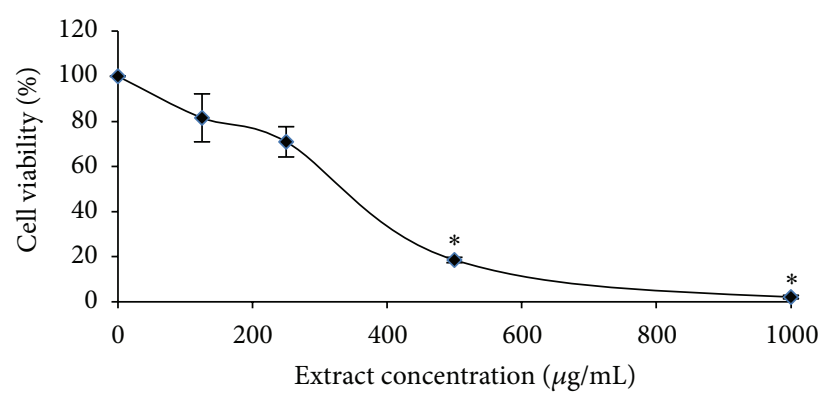

(a)

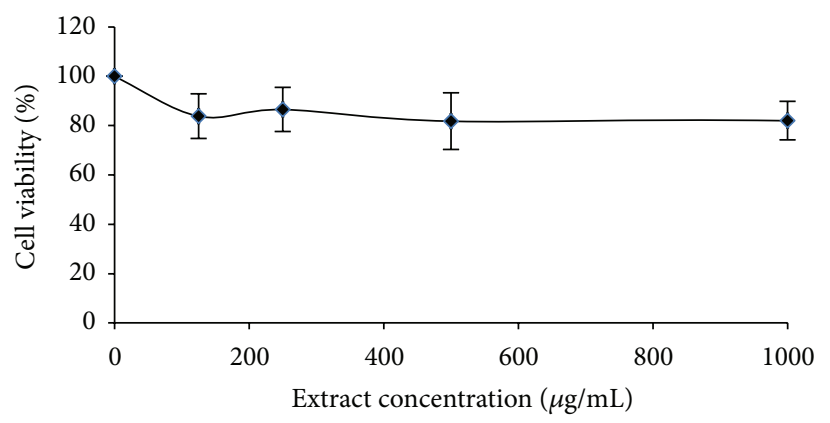

(c)

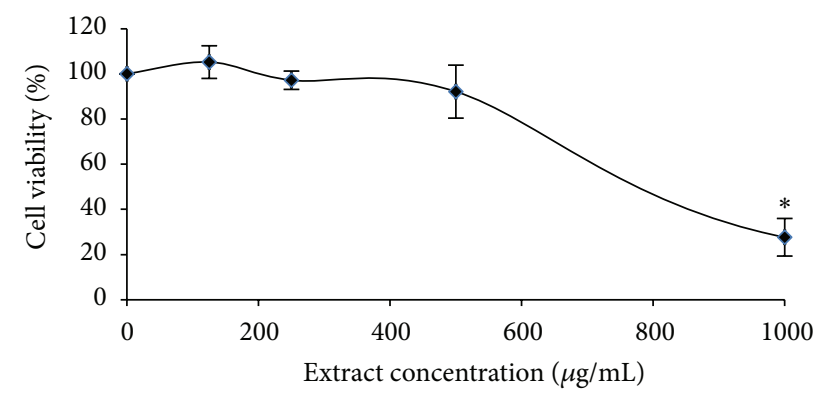

(b)

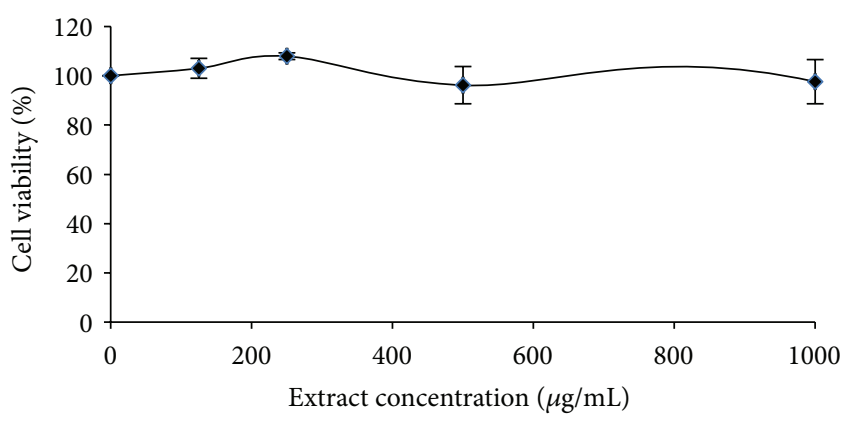

(d)

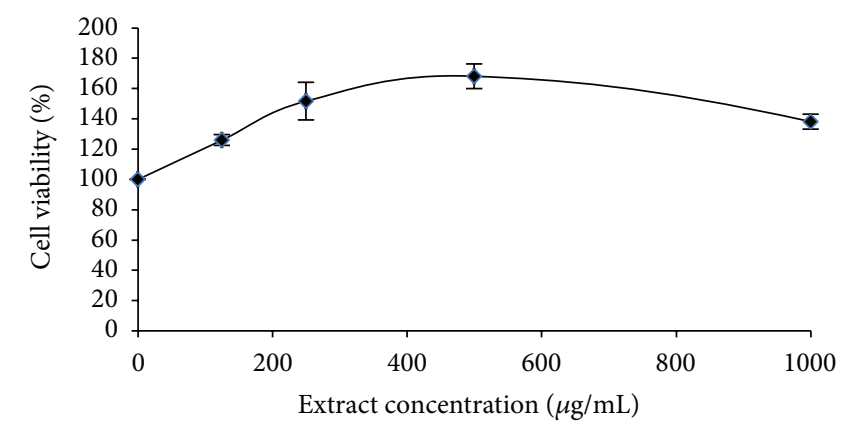

(e)

FIGURE 1: CME exerted selective cytotoxic effect on colorectal carcinoma cells. Percentage viability of (a) HCT 116 colorectal carcinoma cells, (b) HepG2 hepatocellular carcinoma cells, (c) Jurkat E6.1 lymphoblastic leukemic cells, (d) V79-4 Chinese hamster lung fibroblasts, and (e) CCD-841-CoN normal colon epithelial cells following 24-hour treatment with CME. Results are expressed as the means \pm SEM of three independent experiments. ${ }^{*} p<0.05$. Data were compared between the untreated negative control and the treatment groups by using one-way ANOVA.

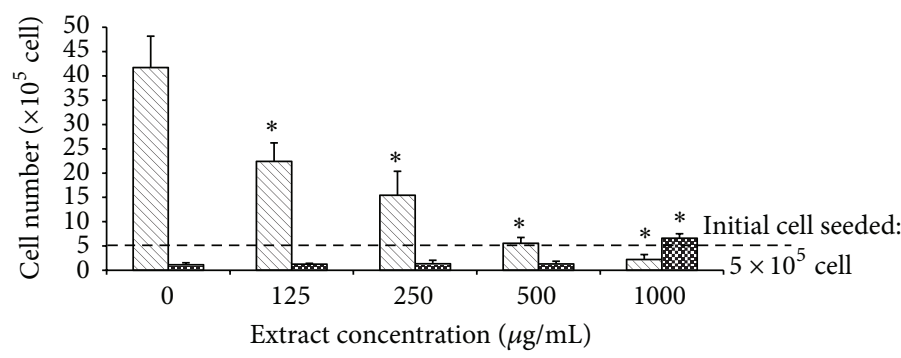

- Viable cell number

ه Dead cell number

FIGURE 2: CME inhibited proliferation of HCT 116 cells. Cell count of HCT 116 cells exposed to different concentrations of CME for 24 hours. The results represent the means \pm SEM of three independent experiments. ${ }^{*} p<0.05$. Data were compared between the untreated negative control and the treatment groups by one-way ANOVA. 


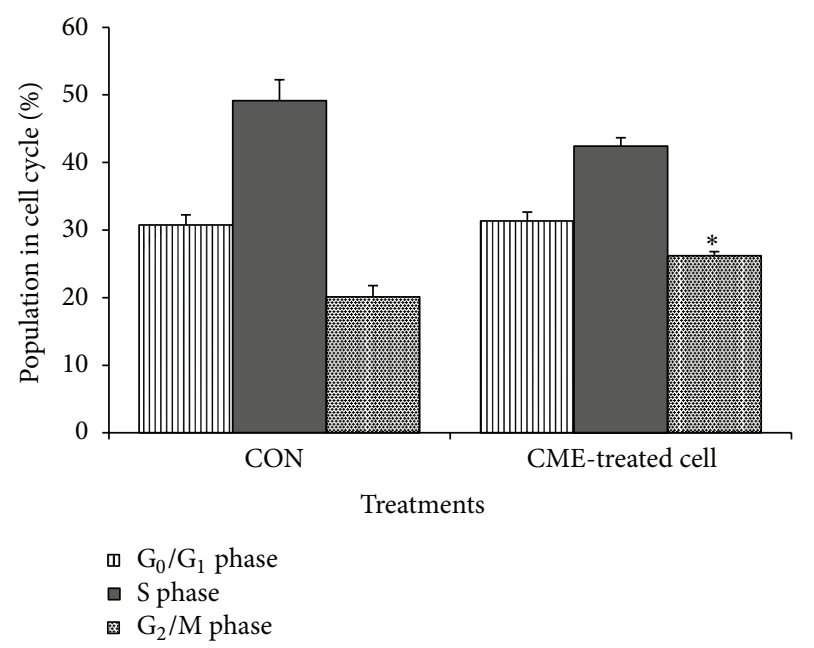

FIGURE 3: CME induced accumulation of cell population in $\mathrm{G}_{2} / \mathrm{M}$ phase. Cell-cycle analysis of HCT 116 cells treated with $500 \mu \mathrm{g} / \mathrm{mL}$ of $\mathrm{CME}$. The results represent the means \pm SEM of three independent experiments. ${ }^{*} p<0.05$. Data were compared between the untreated negative control and the treatment groups by one-way ANOVA.

that $500 \mu \mathrm{g} / \mathrm{mL}$ CME caused an increase in superoxide anion level 1.8-fold as early as 30 minutes and persisted up to 4 hours. Free thiol assessment demonstrated that a 30 minute treatment caused a decrease in glutathione level. The glutathione level in the negative control cells was $283.6 \pm$ 41.0 nmole $\mathrm{GSH} / \mathrm{mg}$ protein, which significantly decreased to $169.7 \pm 6.0$ nmole $\mathrm{GSH} / \mathrm{mg}$ protein after a 30-minute treatment (Figures 5 and 6).

3.6. CME Induced DNA Damage in HCT 116 Cells. Early DNA damage plays a role in halting cell cycle for DNA repair or to trigger apoptosis if the repair mechanism fails. Therefore, alkaline comet assay was conducted, and the phosphorylated $\mathrm{H} 2 \mathrm{AX}$ level was assessed to investigate possible involvement of DNA damage in CME-treated cells. Our data showed that the tail moment of the CME-treated cells increased as early as 30 minutes in a time-dependent manner $(p<$ $0.05)$. Immunoblot analysis demonstrated persistent increase in phosphorylated $\mathrm{H} 2 \mathrm{AX}$ level up to 24 hours in CMEtreated cells compared with the negative control. The overall data emphasized that early DNA damage occurred in CME induced apoptosis (Figures 7 and 8).

3.7. CME Induced MMP Loss in HCT 116 Cells. The role of mitochondria in CME induced apoptosis was further investigated in HCT 116 cells. A significant loss in MMP was observed in the HCT 116 cells treated for 30 minutes. The relative fluorescence mean of HCT 116 cells following a 30minute treatment was approximately sevenfold lower than that of the negative control and remained low for 4 hours. This result highlighted the involvement of mitochondria in CME induced apoptosis (Figure 9).

3.8. CME Contained Phenolic Compounds and Saponin. Phytochemical analysis revealed the presence of phenolic compounds and saponin in CME (Table 1).
TABLE 1: Phytochemical screening of CME.

\begin{tabular}{lc}
\hline Phytochemical content & C168 methanol extract \\
\hline Alkaloid & - \\
Triterpenoid & - \\
Saponin & + \\
Phenolic compound & + \\
\hline
\end{tabular}

\section{Discussion}

Pharmacological applications of herbal formulations as alternative medicines do not reflect an emerging practice. Ancestors used herbal formulations for decades without proper scientific evidence. Herbal formulations have gained scientific interest for their pharmacological activities, including anticancer effects [35-40].

This study is the first to report the antiproliferative effect of CME in human colorectal carcinoma cells. Our data showed that CME significantly suppressed the proliferation of colorectal carcinoma cells with minimal effects on normal colon epithelial cells (Figure 1). This finding is important given that the selective cytotoxic activity of the extract toward cancer cells increases its therapeutic value [41, 42]. An expanding list of studies suggested the selectivity of natural products toward cancer cell lines [22, 24, 41-44]. However, to elucidate the possible toxic effects exerted by CME, an in vivo study should be conducted.

In the present study, CME exerted an antiproliferative effect, as demonstrated by MTT assay (Figure 1). Cell count showed that the viable cell population decreased in a concentration-dependent manner without massive cell death (Figure 2). The discrepancy observed between the MTT assay and the trypan blue dye exclusion test occurred as a result of different endpoints used in the two different assays [30]. These findings demonstrated that CME exerted an antiproliferative effect during early treatment ( 24 hours) and induced apoptosis upon longer treatment period (72 hours). A study on the cinnamon extract reported a similar trend of cytotoxicity [22].

Cell-cycle analysis was performed to investigate the possible events that occurred before cell death. CME treatment increased the $\mathrm{G}_{2} / \mathrm{M}$ population in HCT 116 cells. This result suggests the possibility of a cell-cycle arrest during the 24hour treatment, which explained the reduced proliferation indicated by MTT assay. Studies have proven that active compounds such as 2-hydroxycurcuminoid and subamolide, which were isolated from Curcuma spp. and Cinnamomum spp., respectively, were capable of arresting cell cycle at $\mathrm{G}_{2} / \mathrm{M}$ phase $[22,45]$.

Cell death occurs via different mechanisms, such as apoptosis, necrosis, and autophagy. Apoptosis is often involved as a mode of cell death in response to conventional chemotherapeutic agents as well as natural products $[18,19,29,44,46,47]$. Apoptosis is defined as a mechanically driven form of cell death launched in response to various forms of cellular stress [48]. In the current study, we employed Annexin V-FITC/PI dual staining to differentiate both apoptosis and necrosis. CME exhibited apoptosis-inducing properties (Figure 4) at 


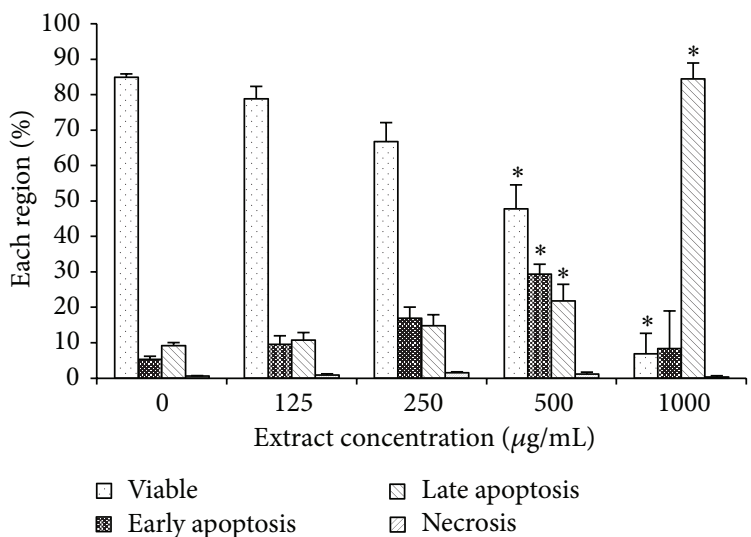

(a)

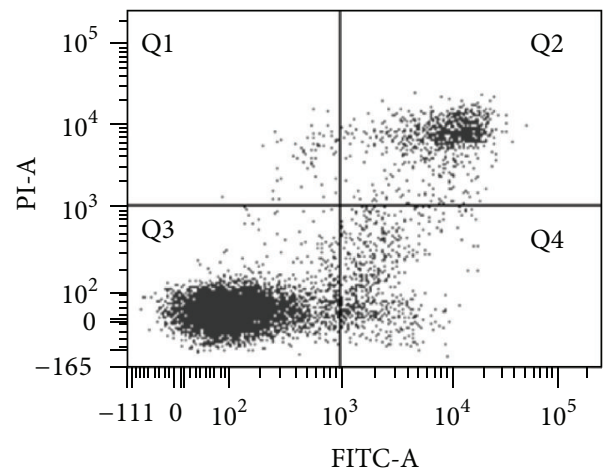

(i) $\mathrm{CON}$

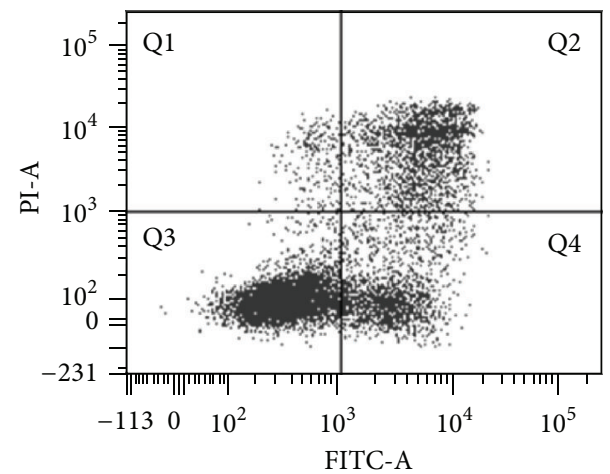

(iii) $250 \mu \mathrm{g} / \mathrm{mL}$

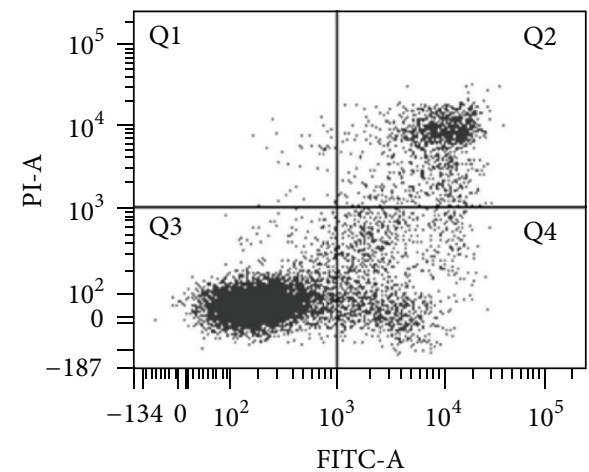

(ii) $125 \mu \mathrm{g} / \mathrm{mL}$

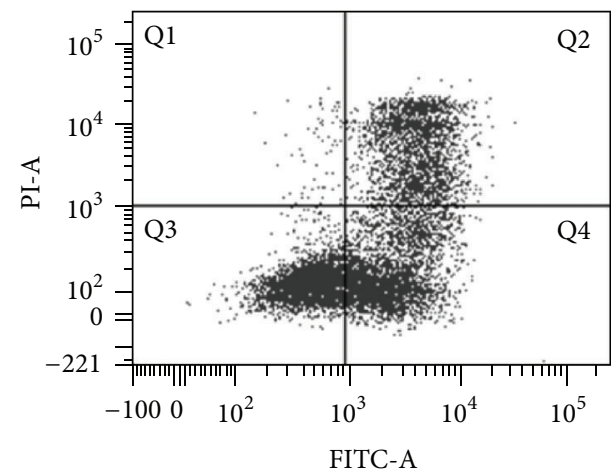

(iv) $500 \mu \mathrm{g} / \mathrm{mL}$

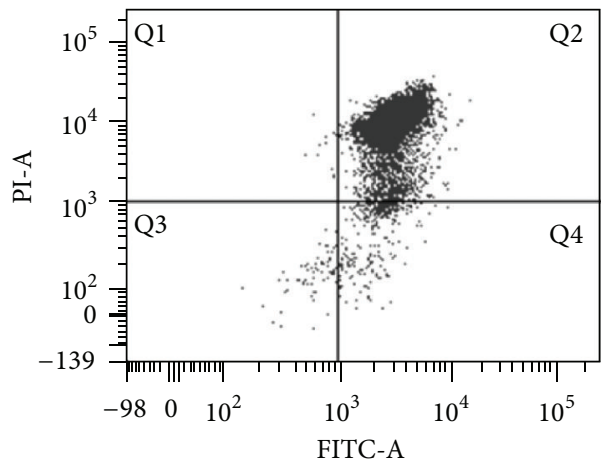

(v) $1000 \mu \mathrm{g} / \mathrm{mL}$

(b)

FIGURE 4: CME induced apoptosis in HCT 116 cells. (a) Mode of cell death investigation on HCT 116 cells treated with different concentrations of CME for 72 hours. (b) Representative dot plots for the (i) control group and the treatment groups treated with (ii) 125, (iii) 250, (iv) 500, and (v) $1000 \mu \mathrm{g} / \mathrm{mL}$ of CME. Data represent the means \pm SEM of three independent experiments. ${ }^{*} p<0.05$. Data were compared between the untreated negative control and the treatment groups. 


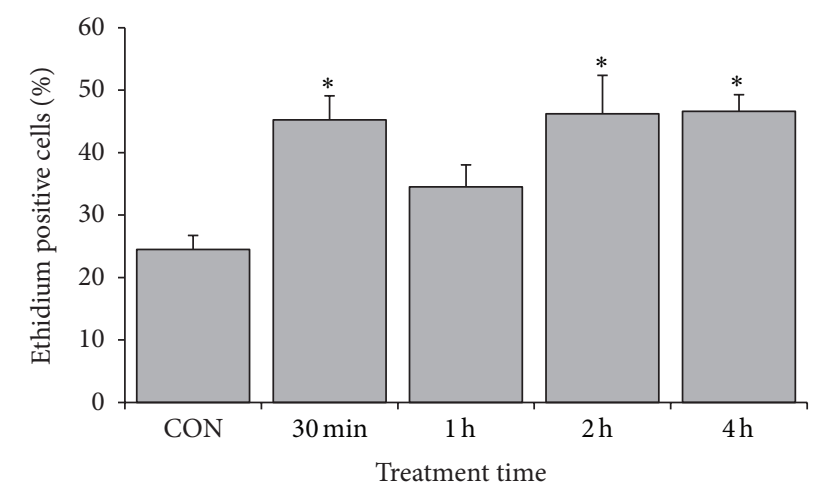

FIgURE 5: CME induced superoxide anion increment in HCT 116 cells during early time point. Percentages of ethidium positive cells indicate the population with superoxide anion accumulation. The results represent the means \pm SEM of three independent experiments. ${ }^{*} p<0.05$. Data were compared between the untreated negative control and the treatment groups.

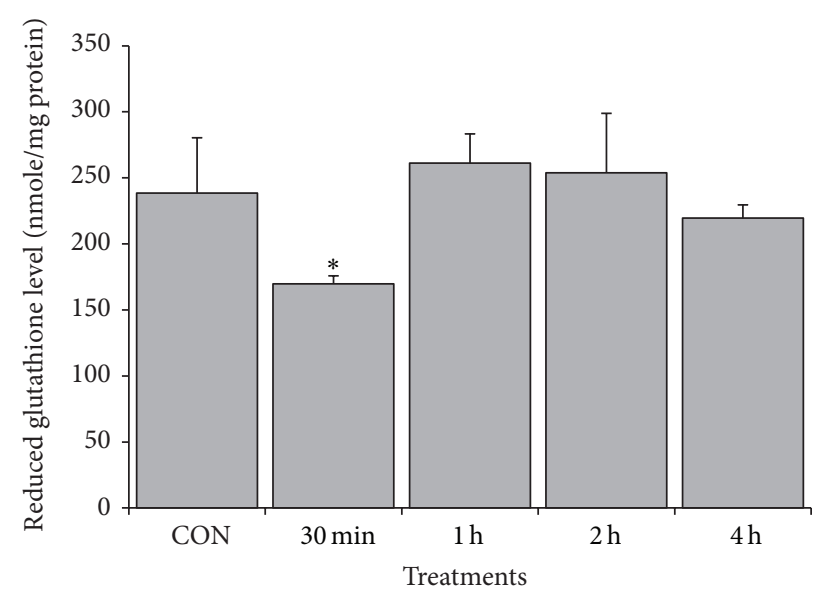

FIgURE 6: CME induced decrease of intracellular glutathione in HCT 116 cells. HCT 116 cells were treated with $500 \mu \mathrm{g} / \mathrm{mL}$ CME for various time points. The results represent the means \pm SEM of three independent experiments. ${ }^{*} p<0.05$. Data were compared between the untreated negative control and the treatment groups.

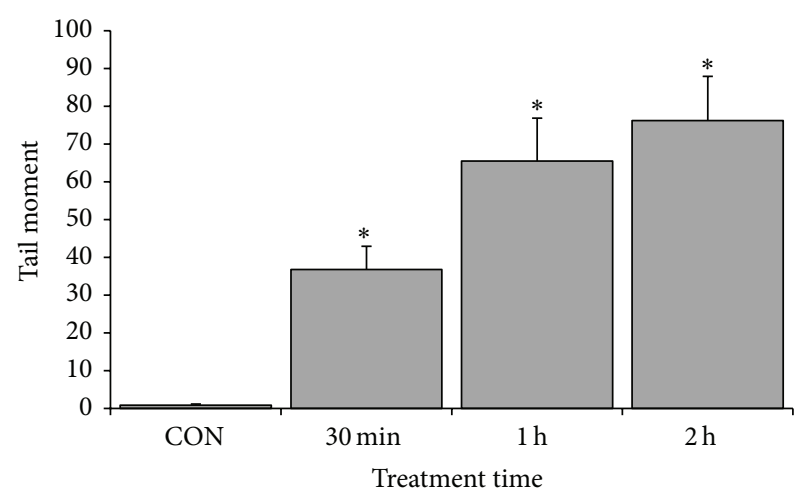

FIGURE 7: CME induced early DNA damage in HCT 116 cells. HCT 116 cells treated with $500 \mu \mathrm{g} / \mathrm{mL}$ CME at various time points and their tail moments. The results represent the means \pm SEM of three independent experiments. ${ }^{*} p<0.05$. Data were compared between the untreated negative control and the treatment groups. a concentration of $500 \mu \mathrm{g} / \mathrm{mL}$, which indicated its therapeutic potential in colorectal cancer. Among the genera available in C168 herbal formulation, Cinnamomum spp., Zingiber spp., and Astragalus spp. are documented to exert antiproliferative effects on human colorectal cancer cells [20-25]. Zingiber officinale extract was proven to induce cell-cycle arrest and apoptosis in HCT 116 cells [23]. Zerumbone, an active compound extracted from Zingiber zerumbet, decreased the proliferation of LS174T, LS180, COLO205, and COLO 320DM cells [24]. Cinnamon, the active compound in Cinnamomum spp., decreased the proliferation of DLD-1 human colon cancer cells [20]. Astragalus saponin extracted from Astragalus membranaceus suppressed p21 expression, inhibited cyclindependent kinase activity, and activated caspase 3 in HT 29 cells, thereby reducing cellular proliferation and promoting apoptosis [25].

In the present study, we observed an early increase in superoxide anion in 30-minute treatment group and a concomitant decrease in the intracellular glutathione level (Figures 5 and 6). Notably, a compensatory increase in glutathione was observed from 1-hour to 4-hour treatment groups (Figure 6). This effect can be attributed to the result of oxidative stress-mediated Nrf-2, ref-1, or NF $\kappa \mathrm{B}$ activation that conferred cytoprotectivity to cells $[31,49,50]$. Although there was a compensatory increase in glutathione, the persistence increase in ROS content was speculated to drive the cell to imbalance redox state and generate oxidative stress. Evidence showed that extract from Zingiber spp. was capable of inducing ROS-mediated cell death [51-53]. 8-Shogaol and 6shogaol isolated from Zingiber spp. are capable of increasing intracellular ROS, leading to caspase-dependent cell death [51-53].

The double-strand break is one of the most lethal DNA lesions triggering cell-cycle arrest and apoptosis [54, 55]. In the current study, DNA damage was determined using alkaline comet assay and confirmed by detection of phosphorylated $\mathrm{H} 2 \mathrm{AX}$, a biomarker for the DNA double-strand break. We observed DNA damage after CME treatment, as indicated by an increase in tail moment and accumulation of phosphorylated H2AX. Notably, no massive cell death occurred up to the 24-hour time point. Therefore, the DNA damage observed was not a secondary event of DNA fragmentation by caspases during late apoptosis. We also showed that early DNA damage preceded cell-cycle arrest and apoptosis, which occur as much later events. This occurrence suggested that DNA damage can be one of the earliest signals of cell death. Previous studies showed that compounds isolated from Cinnamomum spp. can induce DNA damage, as indicated by the upregulation of phosphorylated $\mathrm{H} 2 \mathrm{AX}[54,56,57]$.

The mitochondrion is an important organelle in an apoptotic event. In the current study, a drastic loss of MMP occurred shortly (30 minutes) after CME treatment (Figure 9), suggesting the involvement of mitochondria in CME induced apoptosis. The loss of MMP was associated with the change in inner mitochondrial membrane permeability. Proteins released from the mitochondria, such as cytochrome c (cyt c) and Smac/DIABLO, triggered caspasedependent apoptosis, whereas the apoptosis-inducing factor and endonuclease $\mathrm{G}$ (Endo $\mathrm{G}$ ) activated caspase-independent 


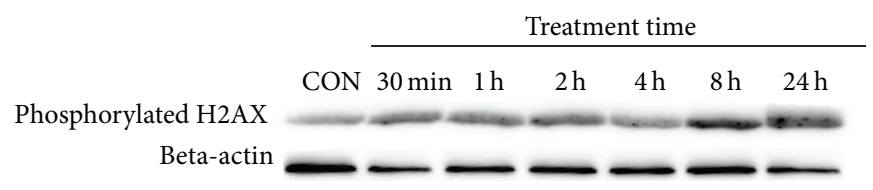

FIgURE 8: CME increased phosphorylated H2AX level in HCT 116 cells. Level of phosphorylated H2AX in HCT 116 cells treated with $500 \mu \mathrm{g} / \mathrm{mL}$ of CME for various time points, assessed by immunoblot analysis.

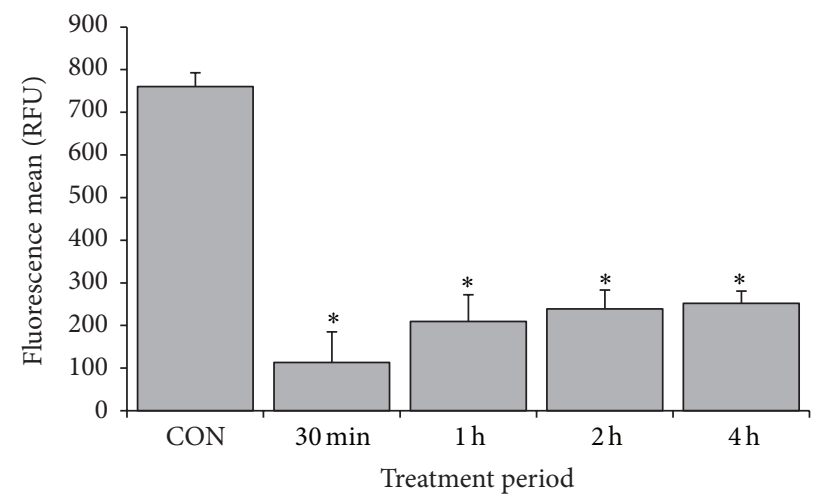

Figure 9: CME induced MMP loss in HCT 116 cells. HCT 116 cells treated with $500 \mu \mathrm{g} / \mathrm{mL} \mathrm{CME}$ at various time points and subjected to TMRE staining. The results represent the means \pm SEM of three independent experiments. ${ }^{*} p<0.05$. Data were compared between the untreated negative control and the treatment groups.

apoptosis [58]. Upstream of apoptotic event, various caspase cascades and cellular machineries are involved in different pathways $[59,60]$. To further understand the upstream target of CME, the caspase signaling pathway must be examined.

In the present study, we observed different levels of cytotoxicity on the five cell lines tested. The selectivity of CME can be attributed to the status of p53 in different cells. p53, also known as the guardian of genome, controls a large number of genes mediating cell-cycle arrest, DNA damage recognition, DNA repair, apoptosis, and senescence [61]. When initiated during cellular stress, p53 initiates transcription of p21, leading to cell-cycle arrest. p53 is also known to induce cell death by forming an inhibitory complex with Bcl-XL and Bcl-2, leading to permeabilization of mitochondrial membrane and leakage of cytochrome c [62]. Furthermore, p53 can directly activate Bax and Bak to initiate apoptosis via the mitochondrial mediated pathway $[62,63]$. Collectively, p53 plays an important role in cellular growth and cell death in response to stress [61]. HCT 116 and HepG2 cells bear a wild-type p53, whereas Jurkat E6.1 and V79-4 cells contain mutated p53 [6467]. No data on the status of p53 in CCD-841-CoN cells are currently available. Considering the central role of p53 in stress response, the intact function of p53 may be important in CME induced cell-cycle arrest and apoptosis. However, this hypothesis requires further investigation.

\section{Conclusion}

Our study emphasized the selectivity of CME toward colorectal cancer cells, with the involvement of oxidative stress and
DNA damage in CME induced apoptosis. This preliminary study needs further attention to identify the possible mechanisms of action of CME to strengthen its therapeutic value in cancer.

\section{Conflict of Interests}

All authors declare no conflict of interests.

\section{Acknowledgments}

The authors thank the National University of Malaysia HEJIM (Industri-2012-023) for the financial support extended. They also thank Dana Lonjakan Penerbitan UKM and Dana Impak Perdana (DIP-2012-024) for partially supporting this study. They are grateful to the Centre of Research and Instrument Management (CRIM) for providing the flow cytometry facility. They thank Inchoice Technology Sdn. Bhd., Malaysia, for supplying the C168 herbal formulation and chemicals. They thank Dr. Chin Kok Yong from the Department of Pharmacology, Faculty of Medicine, Universiti Kebangsaan Malaysia for editing the paper.

\section{References}

[1] C.-Q. Ling, X.-Q. Yue, and C. Ling, “Three advantages of using traditional Chinese medicine to prevent and treat tumor," Journal of Integrative Medicine, vol. 12, no. 4, pp. 331-335, 2014.

[2] X. Li, G. Yang, Y. Zhang et al., “Traditional Chinese medicine in cancer care: a review of controlled clinical studies published in Chinese," PLoS ONE, vol. 8, no. 4, Article ID e60338, 2013.

[3] S.-Y. Yin, W.-C. Wei, F.-Y. Jian, and N.-S. Yang, "Therapeutic applications of herbal medicines for cancer patients," EvidenceBased Complementary and Alternative Medicine, vol. 2013, Article ID 302426, 15 pages, 2013.

[4] T.-C. Chou, "Theoretical basis, experimental design, and computerized simulation of synergism and antagonism in drug combination studies," Pharmacological Reviews, vol. 58, no. 3, pp. 621-681, 2006.

[5] M. R. A. Rashid, A. F. A. Aziz, S. Ahmad, S. A. Shah, and I. Sagap, "Colorectal cancer patients in a tertiary referral centre in Malaysia: a five year follow-up review," Asian Pacific Journal of Cancer Prevention, vol. 10, no. 6, pp. 1163-1166, 2009.

[6] J. Ferlay, P. Autier, M. Boniol, M. Heanue, M. Colombet, and P. Boyle, "Estimates of the cancer incidence and mortality in Europe in 2006," Annals of Oncology, vol. 18, no. 3, pp. 581-592, 2007. 
[7] D. Das, R. Preet, P. Mohapatra et al., "5-Fluorouracil mediated anti-cancer activity in colon cancer cells is through the induction of Adenomatous Polyposis Coli: implication of the longpatch base excision repair pathway," DNA Repair, vol. 24, pp. 15-25, 2014.

[8] E. Van Cutsem, J. M. Borràs, A. Castells et al., "Improving outcomes in colorectal cancer: where do we go from here?" European Journal of Cancer, vol. 49, no. 11, pp. 2476-2485, 2013.

[9] S. Faivre, D. Chan, R. Salinas, B. Woynarowska, and J. M. Woynarowski, "DNA strand breaks and apoptosis induced by oxaliplatin in cancer cells," Biochemical Pharmacology, vol. 66, no. 2, pp. 225-237, 2003.

[10] D. Lawes and I. Taylor, "Chemotherapy for colorectal canceran overview of current management for surgeons," European Journal of Surgical Oncology, vol. 31, no. 9, pp. 932-941, 2005.

[11] M. A. Seyed, I. Jantan, and S. N. A. Bukhari, "Emerging anticancer potentials of goniothalamin and its molecular mechanisms," BioMed Research International, vol. 2014, Article ID 536508, 10 pages, 2014.

[12] T. C. Hsieh, S. S. Chen, X. Wang, and J. M. Wu, "Regulation of androgen receptor (AR) and prostate specific antigen (PSA) expression in the androgen-responsive human prostate LNCaP cells by ethanolic extracts of the Chinese herbal preparation, PC-SPES," IUBMB Life, vol. 42, no. 3, pp. 535-544, 1997.

[13] T. André, C. Boni, M. Navarro et al., "Improved overall survival with oxaliplatin, fluorouracil, and leucovorin as adjuvant treatment in stage II or III colon cancer in the MOSAIC trial," Journal of Clinical Oncology, vol. 27, no. 19, pp. 3109-3116, 2009.

[14] D. S. Thompson, J. D. Hainsworth, K. R. Hande, M. C. Holzmer, and F. A. Greco, "Prolonged administration of lowdose, infusional etoposide in patients with etoposide-sensitive neoplasms: a phase I/II study," Journal of Clinical Oncology, vol. 11, no. 7, pp. 1322-1328, 1993.

[15] F. J. Gianola, P. H. Sugarbaker, I. Barofsky, D. E. White, and C. E. Meyers, "Toxicity studies of adjuvant intravenous versus intraperitoneal 5-FU in patients with advanced primary colon or rectal cancer," American Journal of Clinical Oncology, vol. 9, no. 5, pp. 403-410, 1986.

[16] C.-Z. Wang, X. Luo, B. Zhang et al., "Notoginseng enhances anti-cancer effect of 5-fluorouracil on human colorectal cancer cells," Cancer Chemotherapy and Pharmacology, vol. 60, no. 1, pp. 69-79, 2007.

[17] M. J. O’Connell, J. A. Mailliard, M. J. Kahn et al., "Controlled trial of fluorouracil and low-dose leucovorin given for 6 months as postoperative adjuvant therapy for colon cancer," Journal of Clinical Oncology, vol. 15, no. 1, pp. 246-250, 1997.

[18] N. Pek Leng, N. F. Rajab, T. Sue Mian et al., "Piper betle leaf extract enhances the cytotoxicity effect of 5-fluorouracil in inhibiting the growth of HT29 and HCT116 colon cancer cells," Journal of Zhejiang University-Science B, vol. 15, no. 8, pp. 692700, 2014

[19] M. N. Norfazlina, M. Y. F. Zuraina, N. F. Rajab et al., "In vitro cytotoxicity effects of single and combination Nigella sativa and Zingiber zerumbet extracts on human myeloid leukemia (HL60) cells and its mode of cell death," Journal of Applied Pharmaceutical Science, vol. 4, no. 5, pp. 51-55, 2014.

[20] S. Duessel, R. M. Heuertz, and U. R. Ezekiel, "Growth inhibition of human colon cancer cells by plant compounds," Clinical Laboratory Science, vol. 21, no. 3, pp. 151-157, 2008.
[21] M. A. Lee, H. J. Park, H.-J. Chung, W. K. Kim, and S. K. Lee, "Antitumor activity of 2-hydroxycinnamaldehyde for human colon cancer cells through suppression of $\beta$-catenin signaling," Journal of Natural Products, vol. 76, no. 7, pp. 1278-1284, 2013.

[22] H.-K. Kwon, J.-S. Hwang, J.-S. So et al., "Cinnamon extract induces tumor cell death through inhibition of $\mathrm{NF} \kappa \mathrm{B}$ and $\mathrm{AP1}$," BMC Cancer, vol. 10, no. 1, article 392, 2010.

[23] S. Abdullah, S. A. Z. Abidin, N. A. Murad, S. Makpol, W. Z. W. Ngah, and Y. A. M. Yusof, "Ginger extract (Zingiber officinale) triggers apoptosis and $\mathrm{G}_{0} / \mathrm{G}_{1}$ cells arrest in HCT 116 and HT 29 colon cancer cell lines," African Journal of Biochemistry Research, vol. 4, pp. 134-142, 2010.

[24] A. Murakami, D. Takahashi, T. Kinoshita et al., "Zerumbone, a Southeast Asian ginger sesquiterpene, markedly suppresses free radical generation, proinflammatory protein production, and cancer cell proliferation accompanied by apoptosis: the $\alpha, \beta$ unsaturated carbonyl group is a prerequisite," Carcinogenesis, vol. 23, no. 5, pp. 795-802, 2002.

[25] M. M. Y. Tin, C.-H. Cho, K. Chan, A. E. James, and J. K. S. Ko, "Astragalus saponins induce growth inhibition and apoptosis in human colon cancer cells and tumor xenograft," Carcinogenesis, vol. 28, no. 6, pp. 1347-1355, 2007.

[26] T. Mosmann, "Rapid colorimetric assay for cellular growth and survival: application to proliferation and cytotoxicity assays," Journal of Immunological Methods, vol. 65, no. 1-2, pp. 55-63, 1983.

[27] K. M. Chan, N. F. Rajab, D. Siegel, L. B. Din, D. Ross, and S. H. Inayat-Hussain, "Goniothalamin induces coronary artery smooth muscle cells apoptosis: the p53-dependent caspase-2 activation pathway," Toxicological Sciences, vol. 116, no. 2, pp. 533-548, 2010.

[28] H. Wang, Y. Ye, S.-Y. Pan et al., "Proteomic identification of proteins involved in the anticancer activities of oridonin in HepG2 cells," Phytomedicine, vol. 18, no. 2-3, pp. 163-169, 2011.

[29] S. H. Inayat-Hussain, K. M. Chan, N. F. Rajab et al., "Goniothalamin-induced oxidative stress, DNA damage and apoptosis via caspase-2 independent and Bcl-2 independent pathways in Jurkat T-cells," Toxicology Letters, vol. 193, no. 1, pp. 108-114, 2010.

[30] K. M. Chan, N. F. Rajab, M. H. A. Ishak et al., "Goniothalamin induces apoptosis in vascular smooth muscle cells," ChemicoBiological Interactions, vol. 159, no. 2, pp. 129-140, 2006.

[31] K. M. Chan, R. Hamzah, A. A. Rahaman et al., "The pyranoxanthone inophyllin A induces oxidative stress mediated-apoptosis in Jurkat T lymphoblastic leukemia cells," Food and Chemical Toxicology, vol. 50, no. 8, pp. 2916-2922, 2012.

[32] H. K. Yen, A.-R. Fauzi, L. B. Din et al., "Involvement of Seladin-1 in goniothalamin-induced apoptosis in urinary bladder cancer cells," BMC Complementary and Alternative Medicine, vol. 14, no. 1, article 295, 2014.

[33] G. N. Anyasor, O. Ogunwenmo, O. A. Oyelana, and B. E. Akpofunure, "Phytochemical constituents and antioxidant activities of aqueous and methanol stem extracts of Costus afer Ker Gawl. (Costaceae)," African Journal of Biotechnology, vol. 9, no. 31, pp. 4880-4884, 2010.

[34] S. Saha, E. V. S. Subrahmanyam, C. Kodangala, and S. C. Shastry, "Isolation and characterization of triterpenoids and fatty acid ester of triterpenoid from leaves of Bauhinia variegata," Der Pharma Chemica, vol. 3, no. 4, pp. 28-37, 2011. 
[35] A. De La Taille, O. R. Hayek, R. Buttyan, E. Bagiella, M. Burchardt, and A. E. Katz, "Effects of a phytotherapeutic agent, PCSPES, on prostate cancer: a preliminary investigation on human cell lines and patients," BJU International, vol. 84, no. 7, pp. 845-850, 1999.

[36] B. L. Pfeifer, J. F. Pirani, S. R. Hamann, and K. F. Klippel, "PC-SPES, a dietary supplement for the treatment of hormonerefractory prostate cancer," BJU International, vol. 85, no. 4, pp. 481-485, 2000.

[37] E. J. Small, M. W. Frohlich, R. Bok et al., "Prospective trial of the herbal supplement PC-SPES in patients with progressive prostate cancer," Journal of Clinical Oncology, vol. 18, no. 21, pp. 3595-3603, 2000.

[38] T. Ikezoe, S. S. Chen, D. Heber, H. Taguchi, and H. P. Koeffler, "Baicalin is a major component of PC-SPES which inhibits the proliferation of human cancer cells via apoptosis and cell cycle arrest," The Prostate, vol. 49, no. 4, pp. 285-292, 2001.

[39] M. Bonham, H. Arnold, B. Montgomery, and P. S. Nelson, "Molecular effects of the herbal compound PC-SPES: identification of activity pathways in prostate carcinoma," Cancer Research, vol. 62, no. 14, pp. 3920-3924, 2002.

[40] S.-M. Woo, Y. K. Choi, S.-G. Cho, S. Park, and S.-G. Ko, "A new herbal formula, KSG-002, suppresses breast cancer growth and metastasis by targeting NF- $\kappa \mathrm{B}$-dependent TNF $\alpha$ production in macrophages," Evidence-Based Complementary and Alternative Medicine, vol. 2013, Article ID 728258, 10 pages, 2013.

[41] M. A. M. Ghazali, G. Al-Naqeb, K. K. Selvarajan, M. H. Hasan, and A. Adam, "Apoptosis induction by Polygonum minus is related to antioxidant capacity, alterations in expression of apoptotic-related genes, and S-phase cell cycle arrest in HepG2 cell line," BioMed Research International, vol. 2014, Article ID 539607, 13 pages, 2014.

[42] S. Dong, J.-J. Tang, C.-C. Zhang et al., "Semisynthesis and in vitro cytotoxic evaluation of new analogues of 1-O-acetylbritannilactone, a sesquiterpene from Inula britannica," European Journal of Medicinal Chemistry, vol. 80, pp. 71-82, 2014.

[43] M. M. Lay, S. A. Karsani, S. Mohajer, and S. N. Abd Malek, "Phytochemical constituents, nutritional values, phenolics, flavonols, flavonoids, antioxidant and cytotoxicity studies on Phaleria macrocarpa (Scheff.) Boerl fruits," BMC Complementary and Alternative Medicine, vol. 14, article 152, 2014.

[44] C. Echiburú-Chau, S. Alfaro-Lira, N. Brown et al., "The selective cytotoxicity elicited by phytochemical extract from Senecio graveolens (Asteraceae) on breast cancer cells is enhanced by hypoxia," International Journal of Oncology, vol. 44, no. 4, pp. 1357-1364, 2014.

[45] S.-Y. Kuo, T.-J. Hsieh, Y.-D. Wang, W.-L. Lo, Y.-R. Hsui, and C.Y. Chen, "Cytotoxic constituents from the leaves of Cinnamomum subavenium," Chemical and Pharmaceutical Bulletin, vol. 56, no. 1, pp. 97-101, 2008.

[46] C.-C. Yeh, J.-I. Yang, J.-C. Lee et al., "Anti-proliferative effect of methanolic extract of Gracilaria tenuistipitata on oral cancer cells involves apoptosis, DNA damage, and oxidative stress," BMC Complementary and Alternative Medicine, vol. 12, no. 1, article 142, 2012.

[47] L. T. Ng and S. J. Wu, "Antiproliferative activity of Cinnamomum cassia constituents and effects of pifithrin-alpha on their apoptotic signaling pathways in HepG2 cells," Evidence-Based Complementary and Alternative Medicine, vol. 2011, Article ID 492148, 6 pages, 2011.
[48] Y. A. Hannun, "Apoptosis and the dilemma of cancer chemotherapy," Blood, vol. 89, no. 6, pp. 1845-1853, 1997.

[49] P. D. Ray, B.-W. Huang, and Y. Tsuji, "Reactive oxygen species (ROS) homeostasis and redox regulation in cellular signaling," Cellular Signalling, vol. 24, no. 5, pp. 981-990, 2012.

[50] C. J. Harvey, R. K. Thimmulappa, A. Singh et al., "Nrf2regulated glutathione recycling independent of biosynthesis is critical for cell survival during oxidative stress," Free Radical Biology and Medicine, vol. 46, no. 4, pp. 443-453, 2009.

[51] P.-C. Shieh, Y.-O. Chen, D.-H. Kuo et al., "Induction of apoptosis by [8]-shogaol via reactive oxygen species generation, glutathione depletion, and caspase activation in human leukemia cells," The Journal of Agricultural and Food Chemistry, vol. 58, no. 6, pp. 3847-3854, 2010.

[52] M.-H. Pan, M.-C. Hsieh, J.-M. Kuo et al., "6-Shogaol induces apoptosis in human colorectal carcinoma cells via ROS production, caspase activation, and GADD 153 expression," Molecular Nutrition \& Food Research, vol. 52, no. 5, pp. 527-537, 2008.

[53] N. Nigam, K. Bhui, S. Prasad, J. George, and Y. Shukla, “[6]Gingerol induces reactive oxygen species regulated mitochondrial cell death pathway in human epidermoid carcinoma A431 cells," Chemico-Biological Interactions, vol. 181, no. 1, pp. 77-84, 2009.

[54] H.-M. Wang, K.-C. Cheng, C.-J. Lin et al., "Obtusilactone A and (-)-sesamin induce apoptosis in human lung cancer cells by inhibiting mitochondrial Lon protease and activating DNA damage checkpoints," Cancer Science, vol. 101, no. 12, pp. 26122620, 2010.

[55] J. Yang, Z.-P. Xu, Y. Huang, H. E. Hamrick, P. J. DuerksenHughes, and Y.-N. Yu, "ATM and ATR: sensing DNA damage," World Journal of Gastroenterology, vol. 10, no. 2, pp. 155-160, 2004.

[56] M. Daker, V. Y. Lin, G. A. Akowuah, M. F. Yam, and M. Ahmad, "Inhibitory effects of Cinnamomum burmannii Blume stem bark extract and trans-cinnamaldehyde on nasopharyngeal carcinoma cells; synergism with cisplatin," Experimental and Therapeutic Medicine, vol. 5, no. 6, pp. 1701-1709, 2013.

[57] H.-M. Wang, C.-C. Chiu, P.-F. Wu, and C.-Y. Chen, "Subamolide $\mathrm{E}$ from Cinnamomum subavenium induces sub-G1 cell-cycle arrest and caspase-dependent apoptosis and reduces the migration ability of human melanoma cells," Journal of Agricultural and Food Chemistry, vol. 59, no. 15, pp. 8187-8192, 2011.

[58] I. R. Indran, G. Tufo, S. Pervaiz, and C. Brenner, "Recent advances in apoptosis, mitochondria and drug resistance in cancer cells," Biochimica et Biophysica Acta (BBA)Bioenergetics, vol. 1807, no. 6, pp. 735-745, 2011.

[59] A. Herman-Antosiewicz and S. V. Singh, "Signal transduction pathways leading to cell cycle arrest and apoptosis induction in cancer cells by Allium vegetable-derived organosulfur compounds: a review," Mutation Research-Fundamental and Molecular Mechanisms of Mutagenesis, vol. 555, no. 1-2, pp. 121131, 2004.

[60] U. Ziegler and P. Groscurth, "Morphological features of cell death," News in Physiological Sciences, vol. 19, no. 3, pp. 124-128, 2004.

[61] J. Pflaum, S. Schlosser, and M. Müller, "P53 family and cellular stress responses in cancer," Frontiers in Oncology, vol. 4, article $285,2014$. 
[62] D. Speidel, “Transcription-independent p53 apoptosis: an alternative route to death," Trends in Cell Biology, vol. 20, no. 1, pp. 14-24, 2010.

[63] J. E. Chipuk, T. Kuwana, L. Bouchier-Hayes et al., "Direct activation of bax by p53 mediates mitochondrial membrane permeabilization and apoptosis," Science, vol. 303, no. 5660, pp. 1010-1014, 2004.

[64] Y. Liu and W. F. Bodmer, "Analysis of P53 mutations and their expression in 56 colorectal cancer cell lines," Proceedings of the National Academy of Sciences of the United States of America, vol. 103, no. 4, pp. 976-981, 2006.

[65] Y. Lin, C. Y. Shi, B. Li et al., "Tumour suppressor p53 and $\mathrm{Rb}$ genes in human hepatocellular carcinoma," Annals of the Academy of Medicine Singapore, vol. 25, no. 1, pp. 22-30, 1996.

[66] W. Chaung, L.-J. Mi, and R. J. Boorstein, “The p53 status of Chinese hamster V79 cells frequently used for studies on DNA damage and DNA repair," Nucleic Acids Research, vol. 25, no. 5, pp. 992-994, 1997.

[67] J. Cheng and M. Haas, "Frequent mutations in the p53 tumor suppressor gene in human leukemia T-cell lines," Molecular and Cellular Biology, vol. 10, no. 10, pp. 5502-5509, 1990. 


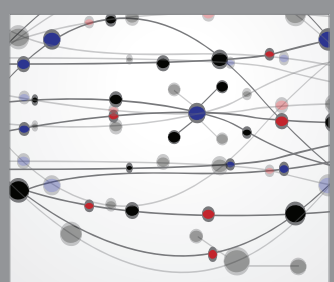

The Scientific World Journal
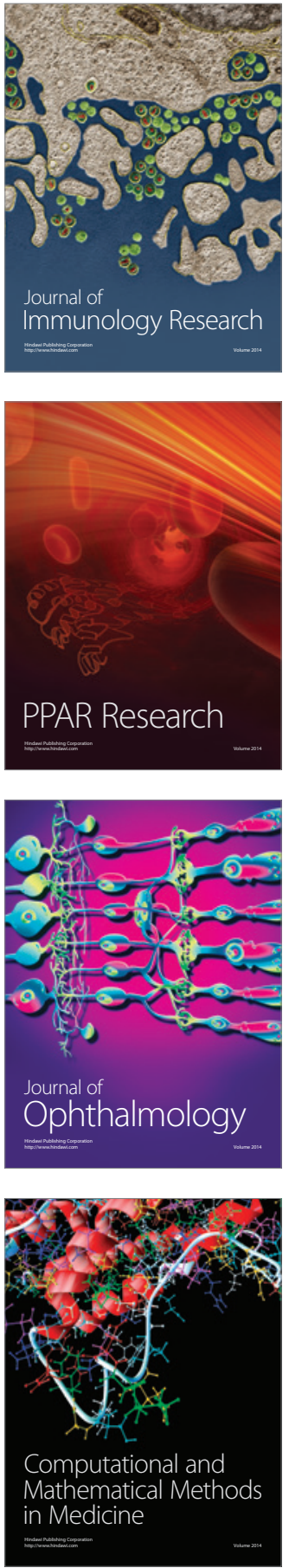

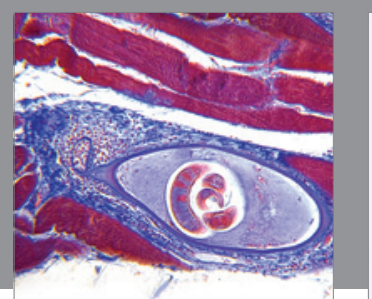

Gastroenterology Research and Practice

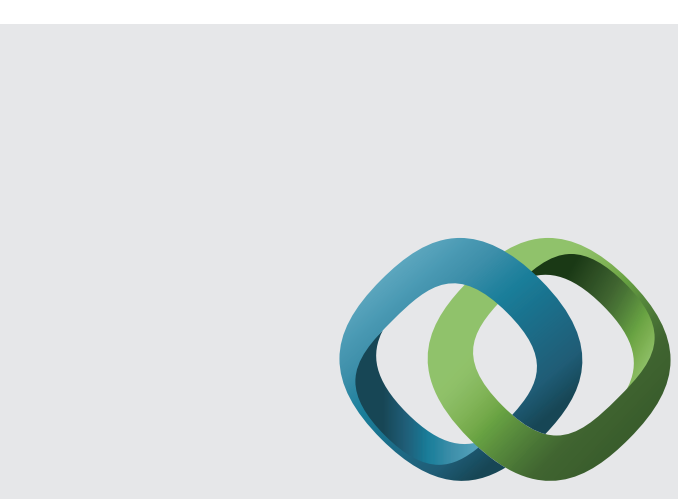

\section{Hindawi}

Submit your manuscripts at

http://www.hindawi.com
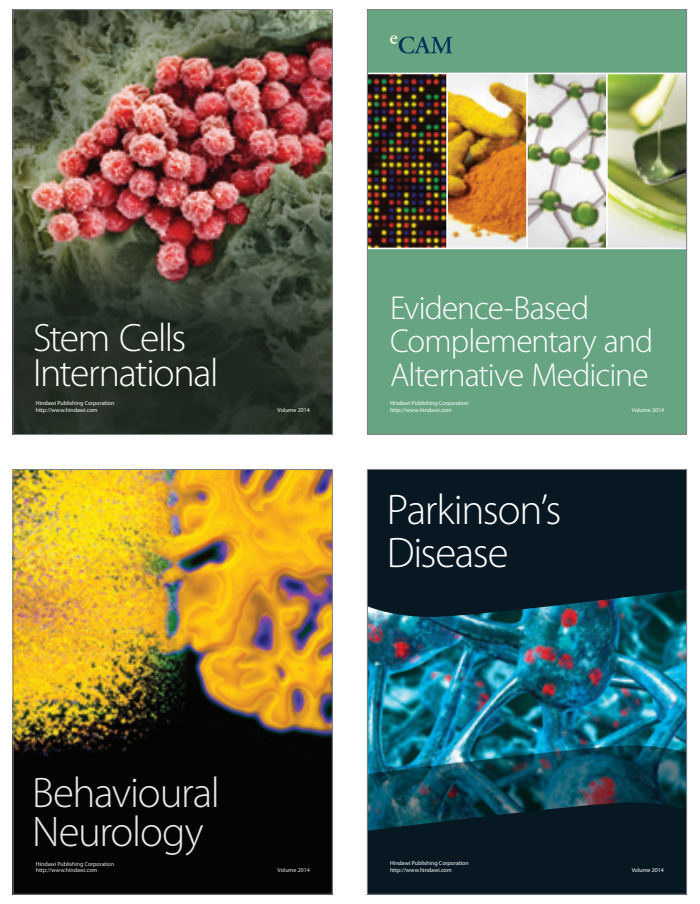
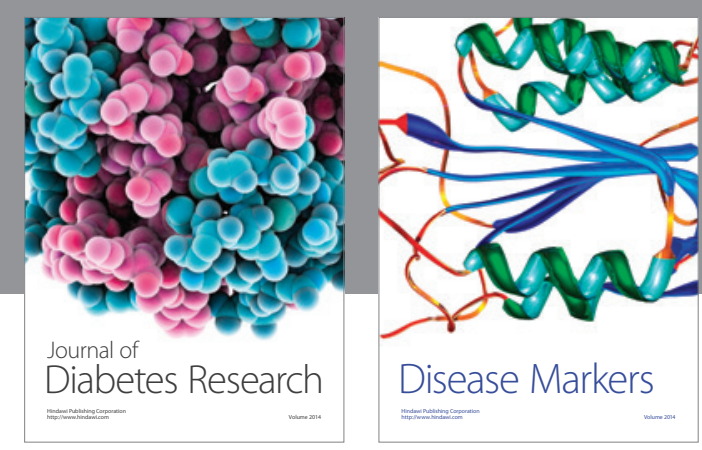

Disease Markers
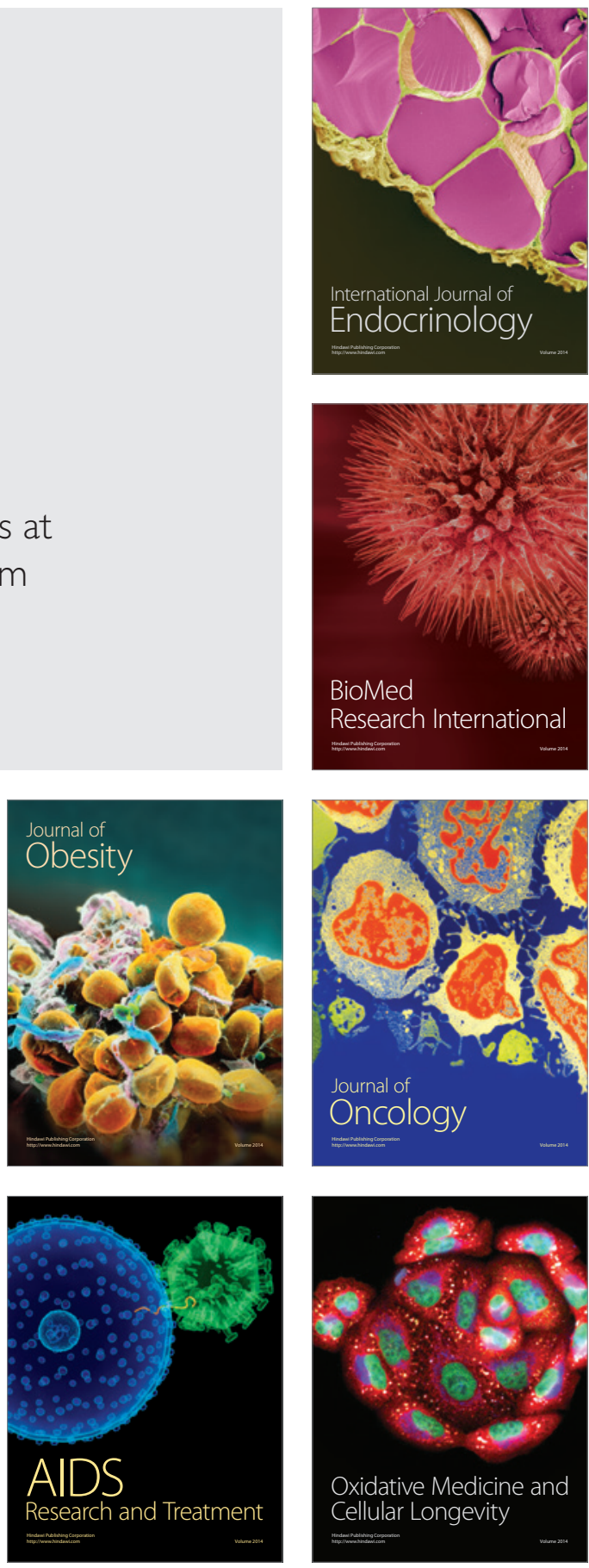